\title{
INTEGRASI PENDEKATAN KUALITATIF DAN KUANTITATIF DALAM PENILAIAN ESTETIKA FASADE BANGUNAN DI KORIDOR JALAN KAYUTANGAN, MALANG
}

\author{
Herry Santosa1, Noviani Suryasari', Triandriani Mustikawati1, \\ Desetri Eka Firosa Adani' ${ }^{1}$, Nur Fauziah' ${ }^{1}$ \\ ${ }^{1}$ Jurusan Arsitektur, Fakultas Teknik, Universitas Brawijaya \\ herrysantosa@ub.ac.id
}

\begin{abstract}
ABSTRAK
Koridor kota merupakan cerminan kualitas ruang kota yang merepresentasikan karakter kotanya, serta merupakan perwujudan arsitektur yang menjadi warisan budaya kota yang sangat perlu untuk dilestarikan dan dijaga kontinuitas dan kesinambungan dengan arsitektur peradaban masa lalu, masa kini dan mendatang. Pengendalian ketat pada kawasan konservasi kayutangan ini sangat penting dilakukan, dikarenakan keberadaan kawasan kayutangan sebagai salah satu koridor kawasan perdagangan dan jasa yang cukup berkembang pesat. Fasade bangunan adalah salah satu kunci bagi sebuah langgam dan ruang arsitektural yang mampu digunakan sebagai guidance bagi tatanan kawasan konservasi koridor kayutangan. Upaya-upaya pengendalian konservasi terhadap fasade bangunan dapat dibantu dengan melakukan penelitian terhadap evaluasi estetika fasade bangunan. Penilaian aspek-aspek keindahan dapat dilakukan dengan dua cara yaitu dengan pendekatan melalui metoda penelitian kualitatif maupun kuantitatif. Penelitian ini menggunakan kombinasi antara penggunaan metoda kualitatif melalui metoda people preferences dengan metoda kuantitatif melalui software Interface Aesthetic Measurement (IAM). Penggunaan kombinasi kedua metoda ini bertujuan untuk menghasilkan penelitian penilaian visual bangunan yang cukup akurat serta mampu digunakan sebagai rujukan terhadap pengembangan software IAM dalam menilai unsur-unsur keindahan visual bangunan pada kasus-kasus serupa.
\end{abstract}

Kata kunci: Estetika, Fasade, Penilaian Visual, Konservasi

\section{ABSTRACT}

Urban streetscape is a reflection of the visual appearance of urban space that represents the character of the City Image as well as an architectural embodiment of the cultural heritage of the city that are essential to be preserved, maintained continuity and sustainability with the architecture civilization of the past, present and future. Due to the rapid growth of trade and service area in kayutangan corridor as one of the conservation streetscape, the strict control of the visual appearance in Kayutangan corridor is indispensable. Building facade is one of the keys to an architectural visual that can be used as a conservation guidance for the visual order of kayutangan corridor. The efforts to control the building facade can be performed by study on aesthetic evaluation. The aesthetic evaluation can be performed in two studies approaches, namely a qualitative and quantitative research methods. This study utilizes a combination of the use of qualitative methods through preferences people method and a quantitative method through Interface Aesthetic Measurement (IAM) software. The utilization of both methods is intended to produce an accurate study of visual evaluation of the building facade and a reference for the development of Interface Aesthetic Measurement (IAM) software in assessing the aesthetic element of building visual in similar cases.

Keywords: Aesthetic, Facade, Visual Evaluation, Conservation 


\section{Pendahuluan}

Koridor kota adalah bagian wilayah kota yang sangat penting untuk diamati pertumbuhan dan perkembangan perwujudan arsitekturnya. Koridor kota juga menjadi cerminan kualitas ruang kota yang merepresentasikan karakter kotanya. Apalagi sebuah bentuk koridor kota yang merupakan perwujudan arsitektur sebagai warisan budaya kota yang sangat perlu untuk dilestarikan dan dijaga kontinuitas dan kesinambungan dengan arsitektur peradaban masa lalu, masa kini dan mendatang. Demikian pula halnya kawasan bersejarah koridor kawasan Kayutangan di kota Malang. Kawasan ini adalah sebuah koridor kota yang merupakan perwujudan arsitektur peninggalan kolonial Belanda dan telah menjadi ruang 'arsitektur kota' Malang yang masuk dalam kawasan konservasi. Sebagai koridor kawasan konservasi, tentunya dibutuhkan pengendalian yang ketat terhadap pola arsitektural bangunan sekaligus ruang secara tiga dimensional yang membentuknya. Konsep-konsep konservasi yang diterapkan haruslah memiliki jawaban yang tepat dalam mempertahankan dan menciptakan kesinambungan pola dan ruang arsitektural yang ada pada koridor kawasan tersebut.

Pengendalian ketat pada kawasan konservasi Kayutangan ini sangat penting dilakukan, dikarenakan keberadaan kawasan kayutangan sendiri juga merupakan salah satu koridor kawasan perdagangan dan jasa yang cukup berkembang pesat. Dimana, tidak semua bangunan beserta ruang dalam koridor yang membentuknya pada kawasan Kayutangan mampu menjadi bangunan kunci bagi sebuah pola (=langgam) dan ruang arsitektural (= ruang tiga dimensional) yang mampu digunakan sebagai 'guidance' bagi tatanan kawasan konservasi koridor kayutangan. Salah satu wujud bentuk pengendalian tersebut adalah terletak pada unsur bentukan fisik bangunan yang membentuk ruang koridor sepanjang kawasan Kayutangan. Bentukan fisik bangunan inilah yang didefinisikan sebagai sebuah fasade koridor kawasan, yang terikat dalam satu kesatuan jalinan visual langgam arsitektural koridor kawasan Kayutangan. Pada tingkatan prosedur ataupun metoda penelitian, penelitian terhadap tatanan fasade koridor tersebut dapat dibagi pada masingmasing fasade bangunan.

Upaya-upaya pengendalian konservasi terhadap fasade bangunan dapat dibantu dengan melakukan penelitian terhadap aspek-aspek keindahan. Oleh karena itu diperlukan adanya penilaian dari masyarakat di berbagai pihak yang berkepentingan tentang nilai keindahan visual bangunan modern di koridor kawasan Kayutangan untuk memperoleh pemetaan perwujudan arsitektur bangunan modern yang dapat menjadi kunci visual bangunan di koridor kawasan Kayutangan, yang nantinya dapat menjadi guidance bagi kesinambungan pertumbuhan dan perkembangan pelestarian koridor kawasan Kayutangan. Penelitian ini bertujuan untuk melakukan penilaian masyarakat dari berbagai pihak yang berkepentingan tentang nilai keindahan visual fasade bangunan modern di koridor kawasan Kayutangan, serta melakukan pemetaan perwujudan arsitektur fasade bangunan modern yang dapat menjadi kunci visual bangunan di koridor kawasan Kayutangan, sekaligus mampu menjadi guidance bagi kesinambungan pertumbuhan dan perkembangan pelestarian koridor kawasan Kayutangan.

\section{Tinjauan Pustaka}

\subsection{Citra dan Karakter Kesetempatan Ruang Arsitektur}

Arsitektur adalah pembuatan tempat yang menyediakan ruang dan mengungkapkan karakter-karakter. Suatu tempat dibentuk oleh suatu situasi kehidupan. Menurut C.N. Schulz 
(1980), arsitektur adalah bentukan yang dibuat manusia untuk mengungkapkan kualitas suatu tempat. Bangunan-bangunan menghadirkan segala kandungan yang ada pada suatu tempat dan mendekatkannya pada manusia. Dengan kata lain, arsitektur hadir sebagai pengungkap genius loci dari suatu tempat. Manusia perlu mengenal genius loci suatu tempat dimana manusia berada, supaya dapat bereksistensi dan dapat mengalami tempat tersebut dengan penuh arti. Karakter suatu tempat, seperti dalam hal penggunaan struktur ruang kota/kawasan, bukan sekedar berfungsi "mewadahi" kegiatan fungsional secara statik. Akan tetapi, juga menyerap makna berbagai kekhasan suatu tempat, seperti: ciri dan sifat-sifat keadaan geografis bentuk tempat, setting lingkungan fisik, komposisi dan figurasi bangunan dengan ruang publik, serta karakteristik kehidupan masyarakat setempat (lokal).

\subsection{Citra Kota dan Karakter Visual Arsitektur Bangunan}

Menurut Darmawan \& Sudarwani (2005:103), komponen karakter fisik arsitektur pada suatu bangunan adalah fasade bangunan, skala ketinggian bangunan, langgam/gaya, material, tekstur dan warna. Selain itu, karakter suatu obyek dipengaruhi oleh beberapa faktor, yaitu personality, status sosial, ekonomi, latar belakang budaya. Upaya pemahaman kota Lingkungan fisik kota terbentuk oleh berbagai unsur tiga dimensi, yaitu sifat rancangan, lokasi dan kaitan posisi elemen satu dengan elemen lainnya, yang merupakan faktor penentu kejelasan ciri-sifat lingkungan tersebut (Sudrajat,1984). Meskipun unsur pembentuk lingkungan perkotaan di berbagai tempat pada dasarnya relatif sama, tetapi susunannya selalu berlainan, sehingga bentuk, struktur dan pola lingkungan yang dapat dipahami dan dicerna manusia pada tiap lingkungan kota senantiasa berbeda-beda. Dibandingkan dengan bentuk lingkungan binaan yang lain, ciri khas kota sebagai karya arsitektur tiga dimensi terletak pada konstruksi keruangannya yang mempunyai skala luas dan rumit.

\subsection{Kualitas dan Pembentuk Visual Kota}

Perancangan kota mendasarkan pada segi-segi kualitas fisik, yang salah satunya adalah kualitas visual. Tanda-tanda visual adalah ciri-ciri utama yang secara fisik dapat dilihat, yang dapat memberikan atribut pada sumber visual dalam suatu sistem visual, sehingga sistem visual tersebut mempunyai kualitas tertentu. Lebih lanjut dikatakan bahwa kualitas visual merupakan suatu atribut khusus yang ada pada suatu sistem visual yang ditentukan oleh nilai-nilai kultural dan properti fisik yang hakiki (Smardon, 1986). Bentley dalam Gultom (2006) berpendapat tanda-tanda visual merupakan suatu ciri atau tandatanda dari obyek/sumber visual yang ditawarkan, sehingga pengamat dapat menginterpretasikan suatu lingkungan sebagai sesuatu yang memiliki makna.

Kaitan visual menurut Hedman (1984) adalah hubungan secara visual antara elemenelemen dalam bangunan dan/atau hubungan visual antar bangunan-bangunan yang ada di lingkungan sekitarnya sehingga terjadi efek kontinuitas visual yang menyeluruh dan menyatu. Relasi visual adalah hubungan yang terjadi karena adanya kesamaan visual antar satu bangunan dengan bangunan lain dalam suatu kawasan, sehingga menimbulkan image khas pada kawasan tersebut (Siswanto dalam Sunarimahingsih, 1995). Vining dan Stevens dalam Darmawan dan Ratnatami (2005) menjelaskan bahwa kualitas visual mencakup aspek kualitas estetika, seperti proporsi, komposisi, pola dan tatanan, imageability yaitu suatu kualitas yang berkaitan dengan image terhadap sesuatu sistem visual dan elemen pembeda pada suatu pemandangan. Ciri atau kekhasan yang paling mudah diamati adalah 
bentuk fisik, karena kesan visual adalah sesuatu yang mudah untuk diserap dan dicerna oleh ingatan manusia (Lynch, 1960).

\subsection{Environmental Aesthetics}

Enviromental aesthetics merupakan gabungan dari dua wilayah penyelidikan, yaitu empirical aesthetics dan environmental psychology. Dalam enviromental aesthetics terdapat skala pengukuran yang biasa digunakan untuk mengukur kedalaman makna dari suatu desain, yaitu Semantic Differential Scales yang dipopulerkan oleh Robert G. Hersberger dan Robert C.Cass. Osgood et al.(1957), Semantic Differential merupakan perkembangan teknik pengukuran general untuk mengukur arti konotatif yang diseleksi berdasarkan penilaian dari pengertian yang diperoleh dari berbagai grup responden pada bentuk arsitektural. Semantic Differential merupakan penilaian-penilaian deskriptif yang didapat dengan menggunakan skala bipolar dari atribut-atribut yang berseberangan, seperti baik-jelek, kuat-lemah, dan aktif-pasif. Hal ini untuk membedakan arti dari beberapa aspek pada bangunan.

\subsection{Computational Aesthetic}

Interface Aesthetic (IA) adalah bagian dari bidang ilmu yang disebut 'Computational Aesthetics'. Dimana dalam menilai IA, baik yang bersifat digital maupun muncul sebagai interface pada sebuah monitor, dibagi ke dalam entitas-entitas dengan sifat dan atribut tertentu. Entitas sendiri merupakan kelompok pixel yang sinambung dan memiliki atribut tertentu, yang menjadi dasar penyatuan pixel-pixel menjadi sebuah entitas. Ada 13 variabel keindahan yang dapat diukur berdasarkan atribut-atribut entitas yang dimiliki oleh sebuah interface (Ngo et.al., 2000 dikutip dalam Purnomo, 2009). Variabel-variabel keindahan tersebut adalah : Measure of balance (BM), Measure of equilibrium (EM), Measure of symmetry (SYM), Measure of sequence (SQM), Measure of cohesion (CM), Measure of unity (UM), Measure of proportion (PM), Measure of simplicity (SMM), Measure of density (DM), Measure of regularity (RM), Measure of economy (ECM), Measure of homogeneity (HM), Measure of rhythm (RHM).

\section{Metodologi}

\subsection{Desain Penelitian}

Penelitian mengenai penilaian estetika fasade bangunan dengan menggunakan dua pendekatan bidang keilmuan environmental aesthetics dengan computational aesthetics. Pendekatan bidang keilmuan yang pertama yaitu bidang ilmu enviromental aesthetics melalui metode people preferences. Dalam metode people preferences terdapat skala pengukuran yang biasa digunakan untuk mengukur kedalaman makna dari suatu desain, yaitu Semantic Differential Scales. Semantic Differential merupakan perkembangan teknik pengukuran general untuk mengukur arti konotatif yang diseleksi berdasarkan penilaian dari pengertian yang diperoleh dari berbagai grup responden pada bentuk arsitektural. Semantic Differential merupakan penilaian-penilaian deskriptif yang didapat dengan menggunakan skala bipolar dari atribut-atribut yang berseberangan, seperti baik-jelek, kuatlemah, dan aktif-pasif. Pendekatan bidang keilmuan yang kedua adalah bidang ilmu computational aesthetic melalui aplikasi software Interface Aesthetic Measurement (IAM). 
Dimana dalam menilai Interface Aesthetic (IA), baik yang bersifat digital maupun muncul sebagai interface pada sebuah monitor, dibagi ke dalam entitas-entitas dengan sifat dan atribut tertentu.

\subsection{Wilayah Studi}

Penelitian mengenal penilaian estetika fasade bangunan ini difokuskan pada koridor Kayutangan di kota Malang. Koridor Kayutangan kota Malang merupakan wilayah koridor kota yang memiliki kekhasan arsitektur kolonial Belanda yang sangat penting untuk dilestarikan. Wilayah penelitian adalah fasade visual bangunan sepanjang koridor Kayutangan, dari bangunan PLN hingga bangunan pusat perbelanjaan Sarinah. Area penelitian dapat dilihat pada peta berikut ini :

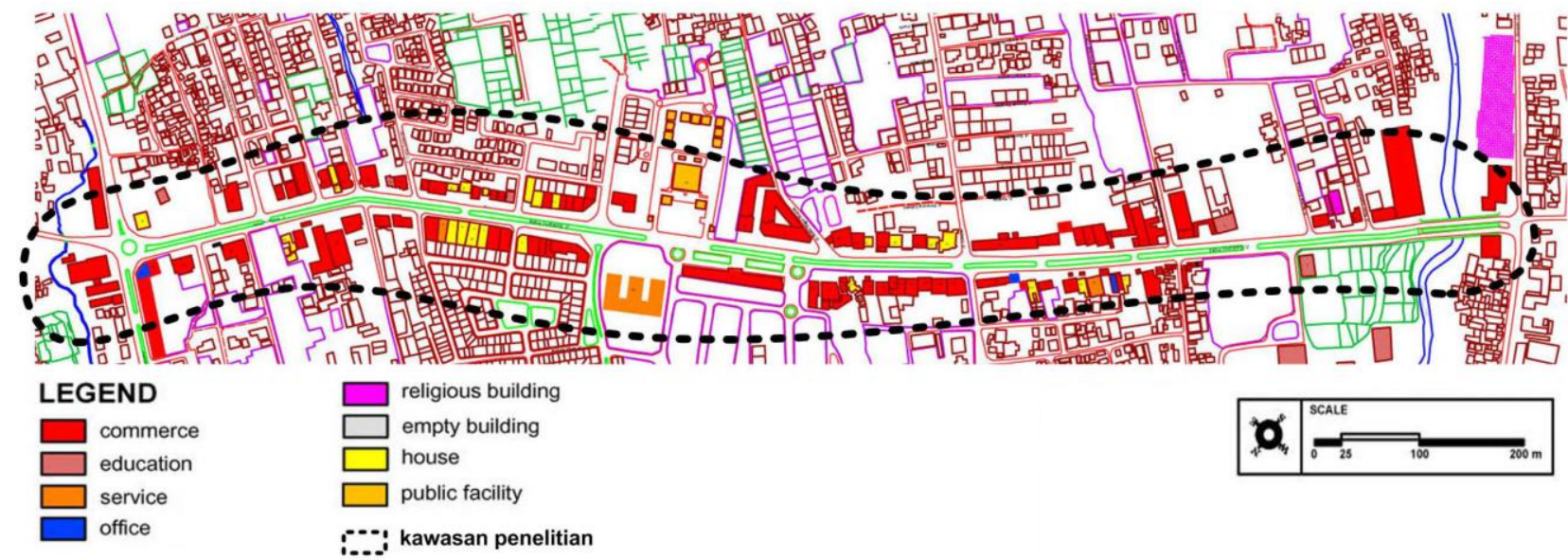

Gambar 1. Peta Koridor Kawasan Kayutangan, Malang

\subsection{Metoda Pengumpulan Data}

Jenis data yang akan digunakan terbagi menjadi 3 bagian. Pertama adalah data primer yang meliputi data observasi lapangan, data dokumentasi visual bangunan di sepanjang koridor Kayutangan serta data preferensi responden yang didapatkan dengan metode kuesiner. Kedua adalah data sekunder meliputi data-data umum kawasan penelitian, yaitu sejarah koridor kawasan Kayutangan, kebijakan pemerintah, serta data-data ekonomi, sosial dan budaya masyarakat kawasan Kayutangan. Ketiga adalah data kepustakaan mengenai estetika façade bangunan, pencitraan kota, karakter dan visual kota, environmental aesthetic, computational aesthetic. Instrumen yang digunakan dalam pengumpulan data meliputi kamera, peta kawasan, alat visual, kuesioner, dan Software Interface Aesthetic Measurement (IAM).

Populasi penelitian ini meliputi semua kalangan masyarakat di kota Malang, yang terdiri dari:

1. Akademis (dosen dan mahasiswa arsitektur)

2. Praktisi.

3. Masyarakat umum

Responden yang dipilih adalah yang berusia lebih dari sama dengan 18 tahun, dengan pertimbangan mereka dapat memberikan penilaian terhadap kualitas visual fasade dengan lebih obyektif dan dapat memahami pertanyaan yang diajukan. Sedangkan metode 
pemilihan sampel yang dipergunakan adalah non-probability sampling. Teknik ini tidak memberi kemungkinan yang sama bagi setiap unsur populasi untuk dipilih menjadi sampel (Nasution, 2004:86). Tidak memperhitungkan jenis kelamin, status sosial dan latar belakang dari responden. Masing-masing kelompok responden diambil sebanyak 30 sampel karena mengikuti batas minimal penggunaan analisa software SPSS. Sehingga jumlah keseluruhan sampel pada penelitian ini adalah 60 orang untuk tiga kelompok responden.

\subsection{Metoda Pengukuran dan Analisis Data}

Pengukuran skala menurut metode Thurstone digunakan untuk menganalisa persepsi masyarakat terhadap kualitas visual pada fasade bangunan sepanjang koridor Kayutangan di kota Malang digunakan. Menurut Nasution (2004:64), skala ini berisi item-item yang disusun menurut tarif intensitasnya, dan yang tinggi sampai yang rendah. Para responden akan diminta untuk menempatkan setiap item pernyataan dalam salah satu dari 7 kategori skala.

Analisa data meliputi analisa deskriptif, analisa persepsi, pengujian Paired Sample Ttest, dan analisa citra dalam skala entitas. Analisis deskriptif merupakan metode untuk menggambarkan data yang dikumpulkan secara sederhana yang disajikan dalam bentuk tabel frekuensi untuk mengatur data ke dalam bentuk yang lebih ringkas. (Nasution dan Umnan, 2007:118).

Analisa persepsi masyarakat pengunjung terhadap kualitas visual pada fasade bangunan sepanjang koridor Kayutangan di kota Malang menggunakan metode analisis statistik deskriptif (frekuensi). Untuk mengetahui persepsi masyarakat terhadap kualitas visual pada bangunan sepanjang koridor Kayutangan di kota Malang, responden diminta untuk menilai beberapa aspek yang menyangkut 13 variabel nilai keindahan dalam skala entitas (Ngo et.al.,2000 dikutip dalam Purnomo, 2009).

Pengujian Paired Sample T-test ini menggunakan software SPSS. Data-data yang diperoleh dari hasil kuisioner oleh responden diolah untuk membandingkan dan mengetahui pendapat masyarakat secara umum, variabel mana yang dipilih masyarakat untuk mempersepsikan kualitas visual pada fasade bangunan sepanjang koridor Kayutangan di kota Malang.

Analisa citra dalam skala entitas mempergunakan bantuan aplikasi software Interface Aesthetic Measurement (IAM). Interface Aesthetic (IA) adalah bagian dari bidang ilmu yang disebut 'Computational Aesthetics'. Ada 13 variabel keindahan yang dapat diukur berdasarkan atribut-atribut entitas yang dimiliki oleh sebuah interface (Ngo et.al., 2000 dikutip dalam Purnomo, 2009).

\subsection{Metoda Sintesis}

Metode sintesis ini merupakan tahapan akhir dari proses analisis data, yang bertujuan untuk menyimpulkan jawaban dari rumusan permasalahan yang ingin didapatkan dari keseluruhan kegiatan penelitian mengenai penilaian estetika fasade visual bangunan sepanjang koridor Kayutangan di kota Malang. Metode sintesis ini berupaya menggabungkan penilaian estetika fasade bangunan tersebut antara pendekatan metoda people preferences dengan pendekatan computational aesthetic melalui aplikasi software Interface Aesthetic Measurement (IAM). 
Variabel-variabel yang akan diamati dalam penelitian ini mengikuti variabel nilai keindahan citra dalam skala entitas yang terdiri dari 13 variabel yang dimiliki oleh sebuah interface visual bangunan (Ngo et.al.,2000 dikutip dalam Purnomo, 2009). Variabel penelitian ini digunakan untuk mempermudah mendeskripsikan karakteristik nilai keindahan fasade visual bangunan sepanjang koridor Kayutangan. Rumusan variabel keindahan yang dipadukan dengan penggunaan skala semantik, adalah sebagai berikut:
1. Measure of balance
2. Measure of equilibrium
: seimbang -
tidak seimbang
3. Measure of symmetry
: selaras
kontras
4. Measure of sequence
: simetri
tidak simetri
5. Measure of cohesion
: berurutan -
tidak berurutan
6. Measure of unity
: terpadu -
: menyatu -
tidak terpadu
7. Measure of proportion
: proporsional-
tidak menyatu
8. Measure of simplicity
: sederhana -
tidak proporsional
9. Measure of density
10. Measure of regularity
11. Measure of economy
12. Measure of homogeneity
: pejal
kompleks
: keteraturan -
transparan
: efektif
semrawut
13. Measure of rhythm
: harmoni -
tidak efektif
tidak harmoni
: dinamis - monoton

\section{Hasil dan Diskusi}

\subsection{Deskripsi Koridor Jalan Kayutangan}

Koridor Jalan Basuki Rahmad di kota Malang merupakan salah satu jalan yang membentuk karakteristik kota Malang. Jalan Basuki Rahmad atau yang lebih dikenal dengan sebutan Jalan Kayutangan ini memiliki nilai historis yang cukup tinggi. Jalan Basuki Rahmad terbentuk dan mengalami perkembangan pesat pada waktu pemerintahan kolonial Belanda. Sampai saat ini pun, Jalan Basuki Rahmad terbukti masih memiliki karakteristik kolonial, yaitu dari sisi tampilan bangunan-bangunan yang masih mencirikan bangunan kolonial, walaupun pada beberapa titik telah muncul bangunan-bangunan modern yang terlihat kontras dengan lingkungan sekitarnya. Beberapa bangunan kolonial yang telah menjadi landmark koridor jalan Kayutangan pun masih berdiri dan difungsikan dengan baik sampai saat ini.

\subsection{Karakteristik Responden}

Responden dalam penelitian ini terdiri dari pihak akademis (dosen, mahasiswa dan praktisi) dan masyarakat umum. Metode pemilihan sampel yang dipergunakan adalah nonprobability sampling. Teknik ini tidak memberi kemungkinan yang sama bagi setiap unsur populasi untuk dipilih menjadi sampel (Nasution, 2004:86). Tidak memperhitungkan jenis kelamin, status sosial dan latar belakang dari responden. Masing-masing kelompok responden diambil sebanyak 30 sampel karena mengikuti batas minimal penggunaan analisa software SPSS. Sehingga jumlah keseluruhan sampel pada penelitian ini adalah 60 orang untuk dua kelompok responden. 
Tabel 1. Data Dasar Responden

\begin{tabular}{|c|c|c|c|}
\hline \multirow{2}{*}{ NO. } & \multirow{2}{*}{$\begin{array}{l}\text { Kategori } \\
\text { Gender }\end{array}$} & \multicolumn{2}{|c|}{ Jenis 60 Responden } \\
\hline & & Laki-laki & Wanita \\
\hline & & 32 & 28 \\
\hline & & $53,33 \%$ & $46,6 \% \%$ \\
\hline \multirow[t]{4}{*}{2.} & Usia & 18-25(tahun) & 36-45 (tahun) \\
\hline & & 26 orang $=43,33 \%$ & 9 orang $=15 \%$ \\
\hline & & 26-35 (tahun) & 46-65 (tahun) \\
\hline & & 19 orang $=31,67 \%$ & 6 orang $=10 \%$ \\
\hline \multirow[t]{2}{*}{3.} & Tingkat Pendidikan & $\begin{array}{l}\text { SMP } \\
0 \%\end{array}$ & $\begin{array}{c}\text { SMA } \\
6 \text { orang }=10 \%\end{array}$ \\
\hline & & $\begin{array}{c}\text { DIPLOMA } \\
10 \text { orang }=16,67 \%\end{array}$ & $\begin{array}{c}\text { SARJANA } \\
44 \text { orang }=73,33 \%\end{array}$ \\
\hline 4. & Asal Responden & $\begin{array}{c}\text { MENETAP (MALANG) } \\
52 \text { orang }=86,67 \%\end{array}$ & $\begin{array}{l}\text { TIDAK MENETAP } \\
8 \text { orang }=13,33 \%\end{array}$ \\
\hline \multirow[t]{4}{*}{5.} & Pekerjaan & $\begin{array}{c}\text { ARSITEK } \\
12 \text { orang }=20 \%\end{array}$ & $\begin{array}{c}\text { DOSEN } \\
14 \text { orang }=23,33 \%\end{array}$ \\
\hline & & $\begin{array}{c}\text { PNS } \\
1 \text { orang }=1,67 \%\end{array}$ & $\begin{array}{c}\text { MAHASISWA } \\
4 \text { orang }=6,67 \%\end{array}$ \\
\hline & & $\begin{array}{c}\text { SWASTA } \\
23 \text { orang }=38,33 \%\end{array}$ & $\begin{array}{c}\text { PRAKTISI } \\
3 \text { orang }=5 \%\end{array}$ \\
\hline & & LAINNY & $=5 \%$ \\
\hline
\end{tabular}

\subsection{Analisis Interface Aesthetic}

Bangunan-bangunan di sepanjang koridor Jalan Kayutangan Malang terbagi menjadi bangunan bergaya nieuw bowen serta bangunan bergaya modern. Pada penelitian ini, hanya bangunan-bangunan bergaya modern saja yang akan dianalisis menggunakan bidang ilmu computational aesthetic melalui aplikasi software Interface Aesthetic Measurement (IAM). Peta lokasi bangunan-bangunan bergaya modern di sepanjang Jalan Kayutangan dapat dilihat pada gambar berikut.

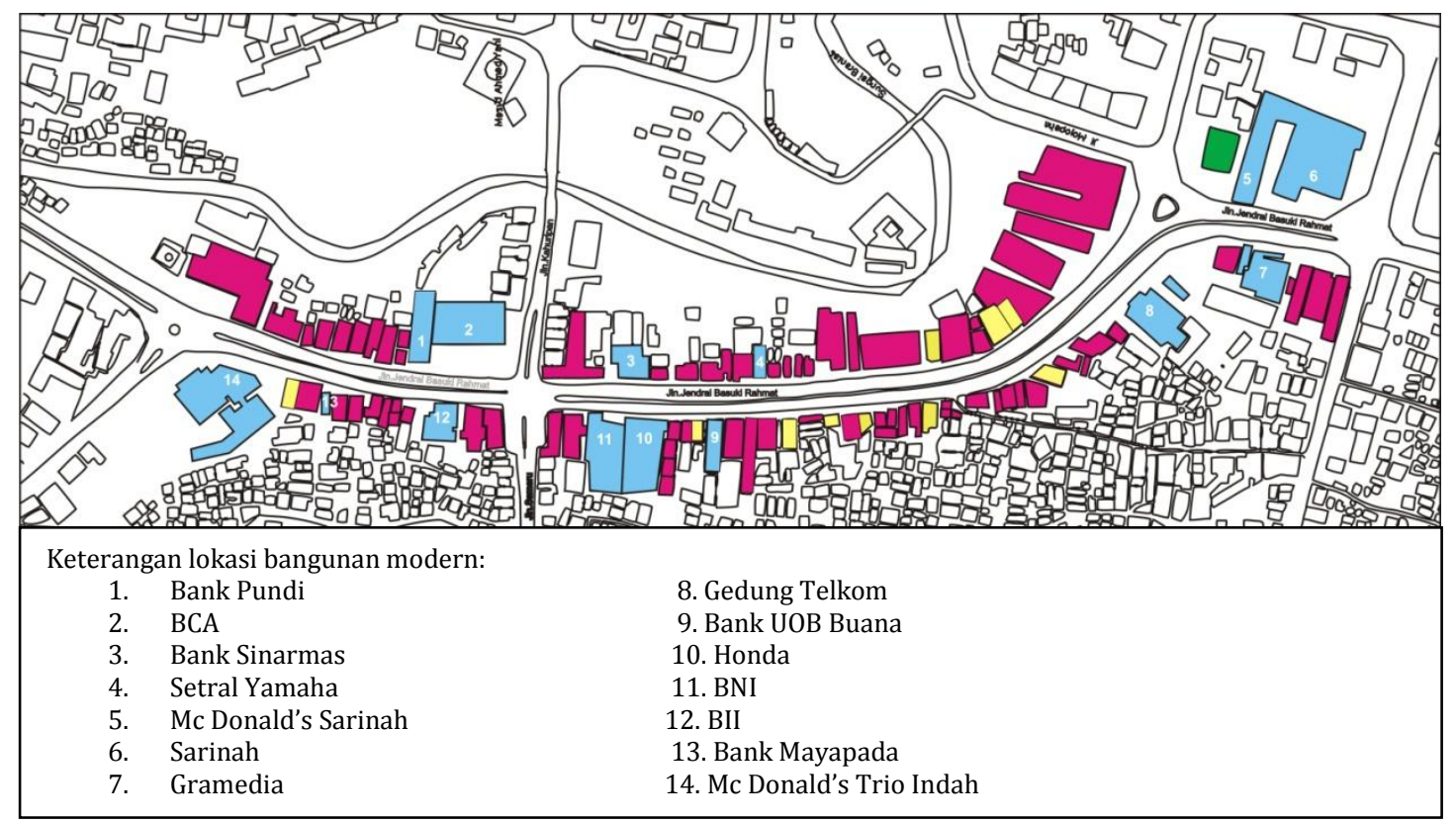

Gambar 2. Pemetaan lokasi bangunan modern di koridor Kayutangan 


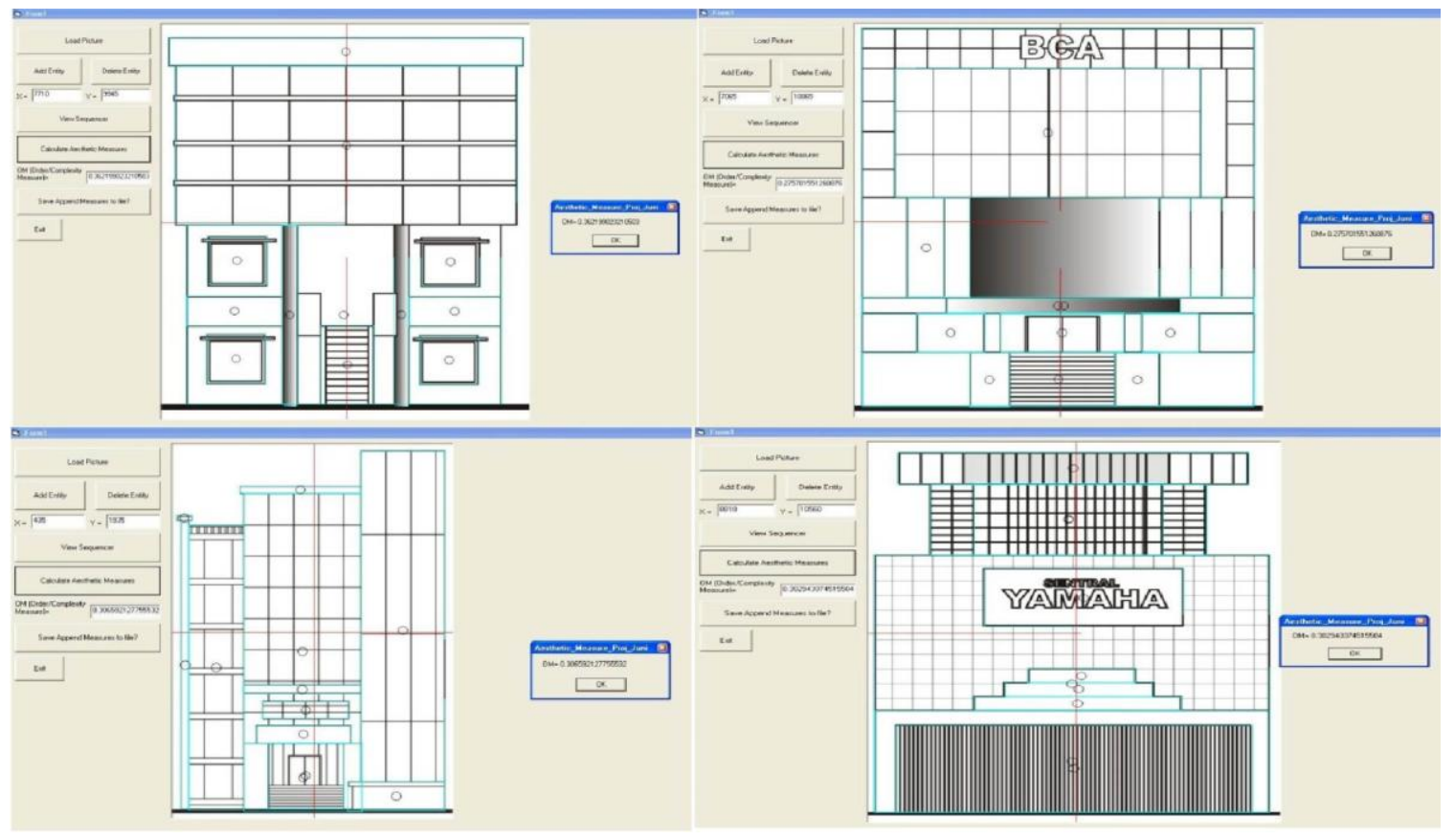

Gambar 3. Proses Penilaian IAM pada Fasade Bangunan Modern di Jalan Kayutangan

Bangunan-bangunan bergaya modern di sepanjang Kayutangan dianalisis satu per satu menggunakan software IAM, sehingga pada akhirnya dihasilkan nilai OM (Order/complexity Measure) yang menunjukkan nilai akhir kompleksitas masing-masing bangunan. Sebelum dimasukkan ke dalam software IAM, masing-masing fasade bangunan harus berbentuk file jpeg dengan warna hitam-putih, agar dapat dideteksi dengan baik oleh software IAM. Beberapa contoh gambar hasil akhir dari penilaian keindahan fasade menggunakan software IAM dari 14 bangunan modern dapat dilihat dalam gambar 3 . Berdasarkan hasil penilaian 13 variabel keindahan masing-masing fasade bangunan modern di Kayutangan dengan menggunakan software IAM, maka dapat diurutkan bangunanbangunan dengan nilai $\mathrm{OM}$ tertinggi sampai dengan bangunan yang memiliki nilai $\mathrm{OM}$ terendah. Hasil tabulasi tersebut dapat dilihat pada tabel berikut:

Tabel 2. Hasil Tabulasi Nilai Kompleksitas Fasade Bangunan Modern Berdasarkan Penilaian Software IAM

\begin{tabular}{|c|c|c|c|c|c|c|c|c|c|c|c|c|c|}
\hline NO & Nama Bangunan & BM & EM & SYM & SQM & CM & UM & PM & SMM & DM & RM & ECM & HM \\
\hline 1 & Bank Mayapada & 0.446 & 0.994 & 0.361 & 0.5 & 0.741 & 0.416 & 0.836 & $7 \cdot 317$ & -0.109 & 0.259 & 0.1 & 1.111 \\
\hline 2 & Bank Pundi & 0.783 & 0.997 & 0.179 & 0.5 & 0.723 & 0.529 & 0.704 & $5 \cdot 55^{6}$ & 2.738 & 0.289 & 8.333 & 0.045 \\
\hline 3 & Honda & 0.726 & 0.999 & 7.427 & 0.75 & 0.769 & 0.297 & 0.708 & $5 \cdot 357$ & -0.178 & 0.232 & 7.692 & 2.143 \\
\hline 4 & Mc Donald's Sarinah & 0.719 & 0.996 & 0.148 & 0.5 & 0.649 & 0.427 & 0.744 & 4.839 & -7.218 & 0.386 & 5.882 & 8.163 \\
\hline 5 & UOB Buana & 0.871 & 0.999 & 0.214 & 0.25 & 0.716 & 0.234 & 0.660 & 6.383 & -0.346 & 0.216 & 9.091 & 1.111 \\
\hline 6 & Bank Sinarmas & 0.446 & 0.991 & -6.784 & 0.5 & 0.622 & 0.522 & 0.716 & 0.06 & 3.432 & 0.286 & 8.333 & 1.607 \\
\hline 7 & Sentral Yamaha & 0.264 & 0.989 & 0.236 & 0.5 & 0.628 & 0.139 & 0.686 & 6.522 & -0.476 & 0.383 & 0.1 & 7.407 \\
\hline 8 & $\mathrm{BCA}$ & 0.593 & 0.998 & 0.216 & 0.5 & 0.733 & 0.099 & 0.755 & 5.660 & -0.590 & 0.282 & 7.692 & 0.0075 \\
\hline 9 & Gramedia & 0.449 & 0.995 & 0.102 & 0.25 & 0.660 & 0.350 & 0.755 & 0.031 & -9.137 & 0.201 & 4.348 & 0.115 \\
\hline 10 & BNI & 0.487 & 0.994 & -0.171 & 0.25 & 0.652 & 0.298 & 0.792 & 0.05 & -0.265 & 0.324 & 5.882 & 4.571 \\
\hline 11 & Telkom & 0.299 & 0.996 & 0.146 & 0.25 & 0.681 & 0.323 & 0.628 & 2.885 & -0.163 & 0.259 & 0.04 & 2.187 \\
\hline 12 & BII & 0.255 & 0.990 & -0.468 & 0.5 & 0.716 & 0.489 & 0.763 & 0.036 & 0.274 & 0.333 & 4.348 & 3.006 \\
\hline 13 & Sarinah & 0.313 & 0.988 & -0.144 & 0 & 0.648 & 0.371 & 0.733 & 3.529 & 0.198 & 0.182 & 0.05 & 1.063 \\
\hline 14 & $\begin{array}{l}\text { Mc Donald's Trio } \\
\text { Indah }\end{array}$ & 0.263 & 0.995 & -0.260 & 0 & 0.584 & 0.471 & 0.657 & 3.371 & 0.143 & 0.336 & 4.167 & 7.730 \\
\hline
\end{tabular}


Berdasarkan hasil tabulasi, didapatkan 7 (tujuh) bangunan memiliki nilai keindahan fasade yang tertinggi menurut software IAM, yaitu Bank Mayapada, Bank Pundi, Honda, Mc Donald's Sarinah, UOB Buana, Bank Sinarmas, dan Sentral Yamaha. Ketujuh bangunan tersebut direkomendasikan sebagai bangunan sample untuk penilaian berdasarkan persepsi masyarakat.

\subsection{Persepsi Visual Estetika Fasade Bangunan}

Dalam penilaian persepsi, responden diharuskan memilih salah satu angka dari tujuh buah skala yang disediakan, seperti di bawah ini:

\begin{tabular}{|l|l|l|l|l|l|l|} 
Negatif 1 & \multicolumn{2}{c}{2} & \multicolumn{2}{c}{4} & \multicolumn{1}{c}{6} & 7 Positif \\
\hline Sangat X & $\mathrm{X}$ & Agak X & Netral & Agak Y & Y & Sangat Y \\
\hline 1 & 2 & 3 & 4 & 5 & 6 & 7 \\
\hline
\end{tabular}

Terdapat penggunaan grafik garis skala penilaian untuk mengetahui di posisi mana mean (rata-rata) skala semantik dari tiap-tiap responden berada. Terdapat tujuh titik yang bernilai sama dengan skala penilaian tiap skala semantik yang dipilih. Titik netral berada di nilai 4, sedangkan untuk nilai rata-rata yang $>4$ memiliki indikasi bahwa nilai rata-rata tersebut cenderung bernilai positif dan untuk nilai rata-rata yang $<4$ memiliki indikasi bahwa nilai rata-rata tersebut cenderung bernilai negatif. Dalam penilaian yang telah dilakukan, terdapat perbedaan persepsi tiap responden dalam melakukan penilaian terhadap estetika tampak depan bangunan modern di sepanjang jalan Kayutangan Kota Malang, yang dilatarbelakangi oleh faktor pendidikan ataupun pengalaman dan selera dari responden.

Hasil penilaian masyarakat terhadap ketujuh bangunan modern di sepanjang jalan Kayutangan, dapat dilihat pada gambar berikut.

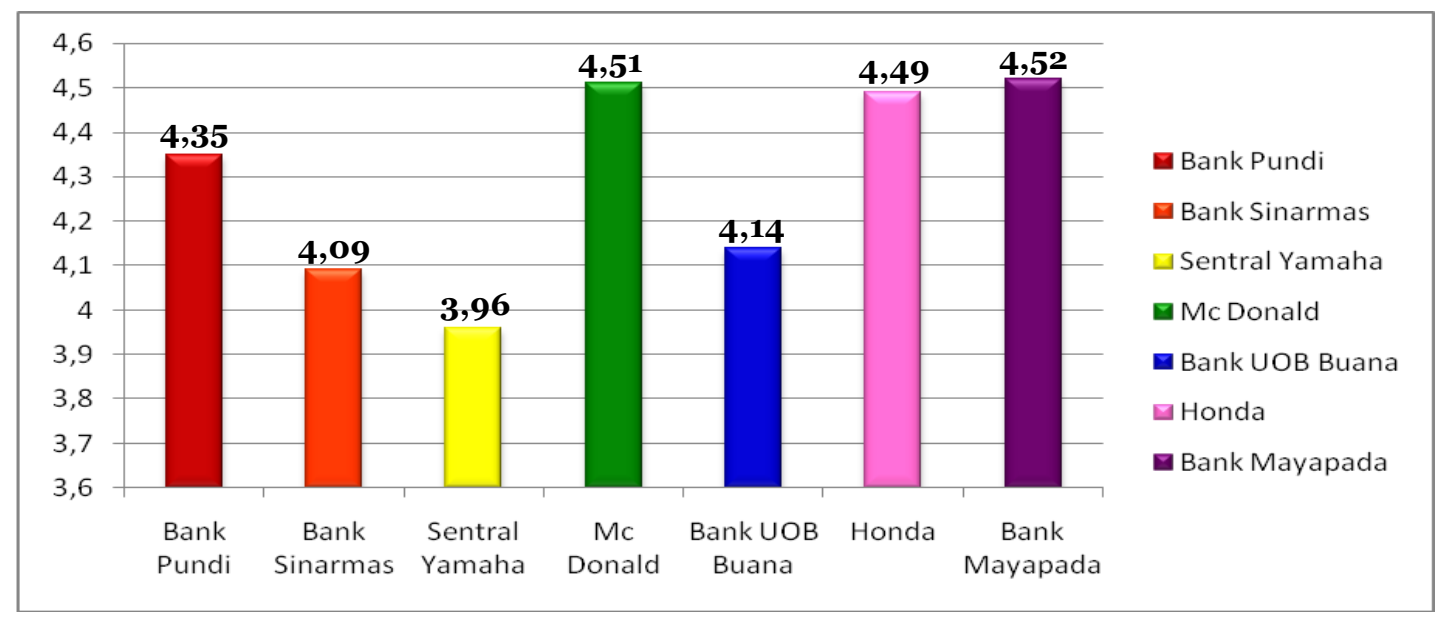

Gambar 5. Grafik Peringkat Persepsi Masyarakat dari ke-7 bangunan modern

Dilihat dari grafik dan diagram di atas, diketahui bahwa dari ketujuh bangunan modern yang dijadikan obyek penelitian di sepanjang jalan Kayutangan, Bank Mayapada yang dinilai memiliki estetika tampak depan bangunan yang paling baik diantara keenam 
bangunan lainnya. Hal ini dapat dilihat dari persepsi kedua golongan responden yang mayoritas menilai positif pada seluruh skala semantik penilaian.

Bila dilihat dari penilaian bangunan terhadap lingkungan sekitar, bank Mayapada memiliki keterpaduan yang baik dengan bangunan di sekitarnya. Proporsi bangunan yang seimbang dengan bangunan disekitarnya menjadikan bangunan memiliki tatanan yang teratur terhadap bangunan disekitarnya. Gaya bangunan yang modern membuat tampilan depan bangunan lebih terlihat sederhana, namun tetap memiliki kesinambungan perulangan unsur-unsur estetika tampak depan bangunan seperti yang dimiliki bangunan lain di sekitarnya.

Jika dinilai berdasarkan konteks bangunan individu (single building), bank Mayapada cukup memiliki tatanan komposisi elemen tampak depan bangunan yang seimbang, dilihat dari penempatan tiap elemen tampak depan bangunan. Selain itu bangunan ini memiliki selubung bangunan yang cukup tertutup sehingga terkesan masif.

\subsection{Diskusi}

Dari hasil penilaian responden sebelumnya, didapatkan 6 bangunan modern yang memiliki rata-rata keseluruhan di atas 4, yang berarti bangunan tersebut secara keseluruhan dinilai positif terhadap lingkungan sekitar dan sebagai bangunan individu, memiliki estetika tampak depan bangunan yang baik. Bangunan tersebut dilihat dari yang paling memiliki nilai rata-rata paling tinggi adalah Bank Mayapada, MC Donalds, Honda, Bank Pundi, Bank UOB Buana, dan Bank Sinarmas.

\section{Simpulan}

Penilaian Interface Aesthetic Measurement (IAM) pada 14 bangunan modern di sepanjang koridor Kayutangan, menghasilkan penilaian 7 bangunan yang memiliki nilai OM (Order/complexity Measure) tertinggi yaitu Bank Mayapada, Bank Pundi, Honda, Mc Donald's Sarinah, UOB Buana, Bank Sinarmas, Sentral Yamaha.

Hasil penilaian berdasarkan preferensi masyarakat menyatakan bahwa masyarakat dari berbagai pihak yang berkepentingan menilai bahwa Bank Mayapada memiliki estetika fasade bangunan yang paling baik diantara keenam bangunan lainnya yang dijadikan sampel penelitian. Penilaian positif masyarakat yaitu pada aspek keterpaduan dengan bangunan di sekitarnya, Proporsi bangunan yang seimbang dengan bangunan disekitarnya sehingga memiliki tatanan yang teratur, serta aspek kesinambungan perulangan unsur-unsur estetika tampak depan bangunan seperti yang dimiliki bangunan lain di sekitarnya. Adapun penilaian positif masyarakat terhadap konteks bangunan individu (single building), yaitu berupa penilaian terhadap tatanan komposisi elemen tampak depan bangunan yang seimbang. Hasil penilaian preferensi masyarakat terhadap estetika fasade Bank Mayapada yang paling baik ini selaras dengan hasil penilaian IAM yang menduduki nilai OM tertinggi.

Pemetaan perwujudan arsitektur bangunan modern yang dapat menjadi kunci visual bangunan di koridor kawasan Kayutangan, yaitu didapatkan 6 bangunan modern yang memiliki rata-rata keseluruhan di atas 4, yang berarti bangunan tersebut secara keseluruhan dinilai positif terhadap lingkungan sekitar dan sebagai bangunan individu, memiliki estetika tampak depan bangunan yang baik. Bangunan tersebut dilihat dari yang paling memiliki nilai rata-rata paling tinggi adalah Bank Mayapada, MC Donalds, Honda, Bank Pundi, Bank UOB Buana, dan Bank Sinarmas. 
Berdasarkan kesimpulan diatas, dapat pula ditarik sebuah kesimpulan, bahwa penggunaan software Interface Aesthetic Measurement (IAM) terhadap penilaian estetika fasade sebuah bangunan dalam kasus fasade bangunan modern di koridor kayutangan, kota Malang ini; memiliki penilaian yang cukup akurat dan bisa diperbandingkan dengan penilaian menggunakan metoda people preferences.

\section{Daftar Pustaka}

Akihary, Huib. (1990). Arsitektur dan Tata Kota di Indonesia 1870-1970. Zuthpen: de Walburg Pers,.

Catanese, Anthony J. et al. (1992). Pengantar Sejarah Perencanaan Perkotaan. Terjemahan. Bandung: Intermatra.

Darmawan, Edy dan Ratnatami, Ariko. (2005). Bentuk Makna Ekspresi Arsitektur Kota Dalam Suatu Kajian Penelitian Badan. Semarang: Universitas Diponegoro.

Handinoto \& Paulus H Soehargo. (1996). Perkembangan Kota dan Arsitektur Kolonial Belanda di Malang, Surabaya: Lembaga Penelitian dan Pengabdian kepada Masyarakat, Universitas Kristen PETRA.

King, Anthony D. (1976). Colonial Urban Development: Cultural, Social Power and Environment. London: Routledge, Kegan Paul.

Nas, Peter J.M. (1986). The Indonesian City: Studies in Urban Development and Planning. Foris: Dordrecht.

Nassar, Jack L. (1988). Environmental Aesthetic: Theory, Research, \& Application. New York: Cambridge University Press.

O'Connor, Zena. (2009). Façade Colour and Judgements about Building Size. Faculty of Architecture, Design and Planning. Sidney: The University of Sidney.

Purnomo, Agus B. (2009). Teknik Kuantitatif untuk Arsitektur dan Perancangan Kota. Jakarta: Rajawali Press.

Parfect, M. \& G. Power. (1997). Planning for Urban Quality: Urban Design in Towns and Cities, London and New York: Routledge.

Pothorn, Herbert. (1983). A Guide to Architectural Styles. Oxford: Phaidon Press, Ltd.

Sumalyo, Yulianto. (1993). Arsitektur Kolonial Belanda di Indonesia. Yogyakarta: Gadjah Mada University Press.

Wikantiyoso, R., dan P. Tutuko. (2009). Kearifan Lokal: Dalam Perencanaan dan Perancangan Kota untuk Mewujudkan Arsitektur Kota yang Berkelanjutan. Jurusan Teknik Arsitektur UNMER Malang: Group Konservasi Arsitektur \& Kota.

Wiryomartono, A. Bagoes P. (1995). Seni Bangunan dan Seni Bina Kota di Indonesia: Kajian Mengenai Konsep, Struktur, dan Elemen Fisik Kota Sejak Peradaban Hindu-Buddha, Islam Hingga Sekarang. Jakarta: PT. Gramedia Pustaka Utama.

Zahnd, Markus. (1999). Perancangan Kota Secara Terpadu: Teori Perancangan Kota dan Penerapannya. Yogyakarta: Penerbit Kanisius. Semarang: Soegijapranata University Press. 